This report was prepared as an account of work sponsored by an agency of the United States Government. Neither the United States Government nor any agency thereof, nor any of their employees, makes any warranty, express or implied, or assumes any legal liability or responsibility for the accuracy, completeness, or usefulness of any inforination, apparatus, product, or process disclosed, or represents that its use would not infringe privately owned rights. Reference herein to any specific commercial product, process, or service by trade name, trademark, manufacturer, or otherwise does not necessarily constitute or imply its endorsement, recommendation, or favoring by the United States Government or any agency thereof. The views and opinions of authors expressed herein do not necessarily state or reflect those of the

\title{
The Chernobyl Accident
}

\section{Herbert Kouts}

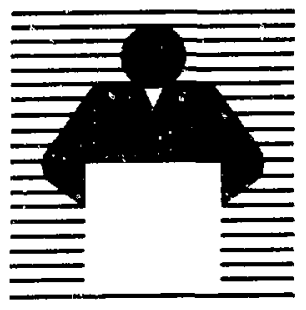

Number 227

September 24, 1986

\section{BROOKHAVEN NATIONAL LABORATORY}

Associated Universities, Inc.

Under Contract No. DE-AC02-76CH00016 with the 


\section{DISCLAIMER}

This report was prepared as an account of work sponsored by an agency of the United States Govenment. Neither the United States Government nor any agency thereof, nor any of their employees, nor any of their contractors, subcontractors, or their employees, makes any warranty, express or implied, or assumes any legal liability or responsibility for the accuracy, completeness, or usefulness of any information, apparatus, product, or process disclosed, or represents that its use would not infringe privately owned rights. Reference herein to any specific commercial product, process. or service by trade name, trademark, manufacturer, or othenwise, does not necessarily constitute or imply its endorsement, recommendation, or favoring by the United States Government or any agency, contractor or subcontractor thereof. The views and opinions of authors expressed herein do not necessarily state or reflect those of the United States Government or any agency, contractor or subcontractor thereof.

Printed in the United States of America

$$
\text { Available from }
$$

National Technical Information Service

U.S. Department of Commerce

5285 Port Royal Road

Springfield, VA 22161

NTIS price codes:

Printed Copy: A02; Microfiche Copy: A01 


\title{
The Chernobyl Accident
}

\author{
Herbert Kouts
}

This Brookhaven lecture is different from most. It is customary in this series for the lecturer to discuss research he has been doing. The objective is usually to acquaint the Laboratory's research staff with activities in specialist areas, because the breadth of research at Brookhaven is wide, indeed.

I will be doing something very different. The concern over the Chernobyl accident has been very high, and interest in it has been intense. Even in some scientific circles there is a great deal of misinformation and misunderstanding of radiation, in general, and of this accident and its consequences, in particular. 1 have had somewhat more involvement than most in reviewing the information available and interpreting it, so I have been asked to give this lecture here today on this subject.

But in giving this talk, 1 am not yielding to any desire to present the sensational or the morbid aspects of the matter. 1 feel only compassion and sympathy for those in the Soviet Union who have suffered through this event. I agreed to undertake this because it is important that the facts in the matter become understood, as far as we know them, and because there are lessons to be learned and used to avoid any repetition of this unfortunate accident.

The first indication outside the Soviet Union that anything unusual had occurred was on the evening of April 27, 1986, at a radiation monitoring station in Finland. This was about forty hours after the accident. Radiation levels of between 70 and 100 microradians per hour were observed at detectors that measured external exposure rates. These were levels several times the normal background rates. In retrospect, it is clear that the early, high levels were caused by a rain shower, that brought down activity from the clciad of fission products, the edge of which was over the monitoring station.

At first, it was thought that the activity was a minor radiation peak of a kind that had been seen in earlier years: melting snow in the spring liberated radon that had been accumulating over the winter under the snow blanket, fed by decay of uranium and thorium distributed naturally over the earth. But the next morning. other monitoring stations in other parts of the country also reported high radiation readings. At the same time, higher than normal radiation levels were observed at the Forsmark nuclear power station in Sweden. A quick check showed that there was no local source of radiative emissions to explain this finding.

Other measurements in Sweden quickly made it clear that the radioactivity was not the result of a nuclear explosive device, like a bomb, but that it was the result of some kind of nuclear reactor plant release in the direction of the Soviet Union.

At 9 PM on the 28th of April, the Soviet Union announced that an accident had occurred at the Chernobyl nuclear power station in the Ukraine. This was two days and nineteen hours after the accident. The Soviet Union has been criticized for keeping quiet about the event for so long. The criticism is justified. By implication, the Soviet government has admitted it by taking a leading role in calling for a procedure requiring that early information on any future nuclear accident be passed through the IAEA to the rest of the world.

To make the accident understandable, I will give a description of the nuclear plant. I will try to do this in a way that is not too technically complicated, and I will concentrate on those features of the plant involved in the events that took place.

First of all, the Chernobyl Unit 4 nuclear plant has a nuclear reactor of the type known in the Soviet Union as RBMK. These initials stand for the fact that it has a graphite moderator and it is cooled by boiling ordinary water. The graphite is a large structure of blocks containing the uranium fuel in pressure tubes which are about 3-1/2 inches in diameter. The tubes also serve as channels for the water which cools the uranium fuel and which is converted to steam to drive the two turbine-generators. Each pressure tube is made of an alloy of zirconium, a 
metal chemically similar to tin. Zirconium has properties that make it very good for use in nuclear reactors, especially those in which water is used at very high temperatures.

The RBMK is thus a boiling water reactor, of the pressure-tube type. Figure 1 shows schematically how the vertical channels are used in generating steam. Each fuel channel contains a number of uranium oxide fuel rods. The water entering at the bottom has a temperature about $25^{\circ} \mathrm{F}$ below the operating temperature, which is about $540^{\circ} \mathrm{F}$. As the water moves up the channel toward the exit at the top, it is heated by the uranium oxide fuel and the surrounding graphite, and it begins to boil. About $14 \%$ of the water is converted to steam before it leaves the presslire tube.

The Chernobyl reactor had 1661 of these pressure tubes, each containing a fuel element with two layers each of 18 fuel rods. The reactor was loaded on-line, which means that fuel elements were changed while the reactor was in operation. This was done through use of a large, heavy refueling machine in the room above the reactor, which removed an end cap from the fuel channel, took out the spent element, and put in a new fuel element.

Figure 2 shows how the steam was used. The mixture of $14 \%$ steam and $86 \%$ water from the pressure tubes was distributed by a complex series of pipes to steam drums, or steam separators. The steam drum is an old-fashioned

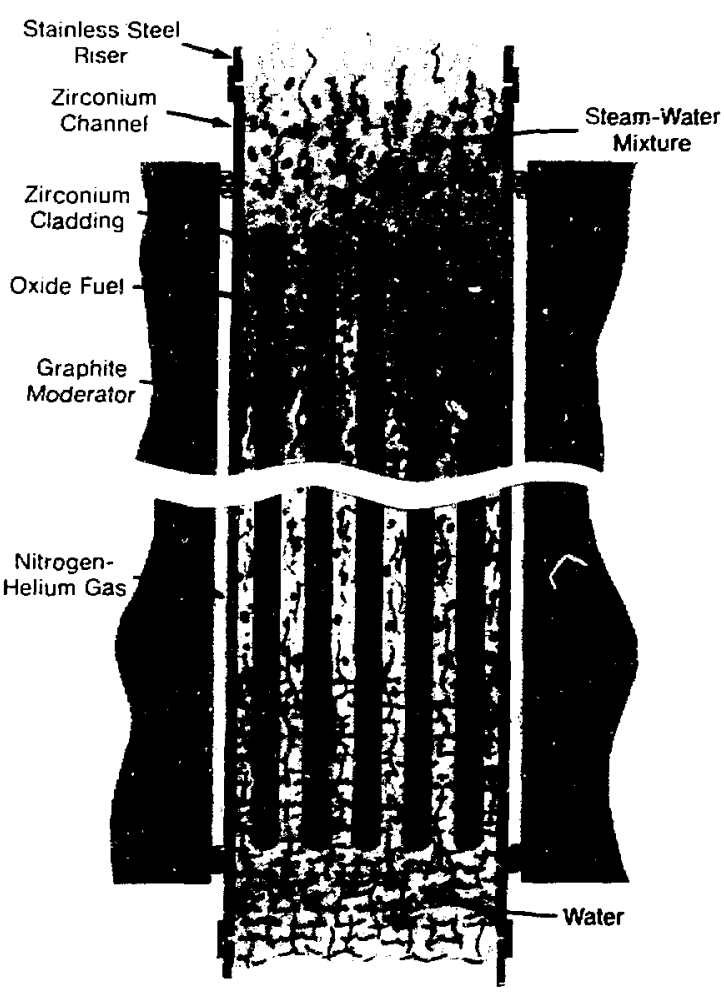

Figure 1. Fuel Channel

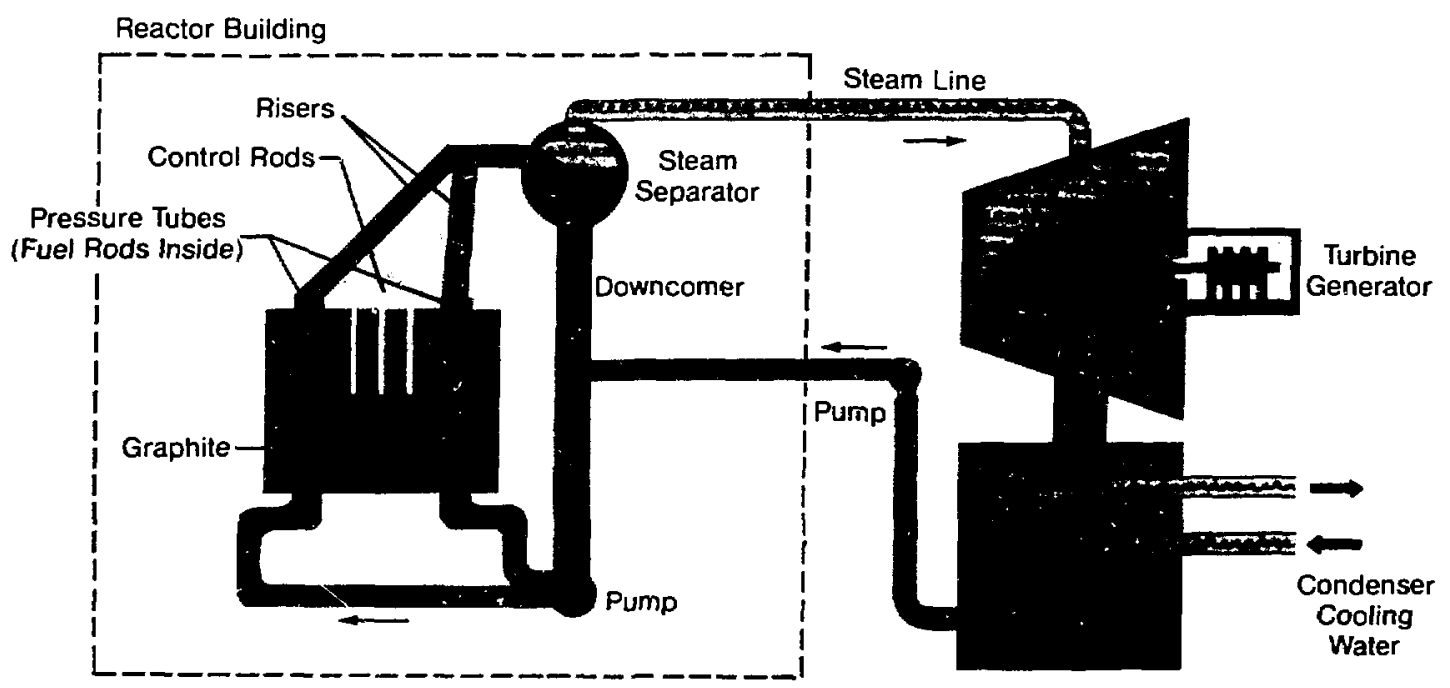

Figure 2. Schematic Diagram of the RBMK-1000. 
device for separating the steam from the water. The water-steam mixture pours into the drum, which is an ordinary cylindrical tank lying on its side, and the two phases separate just as they do in a kettle, with the steam at the top and the water or the bottom. The steam is taken off at the top to drive the turbine, and the water is taken off at the bottom to be returned to the reactor.

The steam is at a reduced temperature and pressure upon exiting the turbine. It is condensed into water by passing it over condenser tubes filled with flowing cooling water. The condensate, called "feedwater," is pumped to join the other stream from the steam drum, called the "recirculation flow." Recirculation flow is at a temperature near the boiling point at the pressure characteristic of the reactor exit. Feedwater is colder than this. The mixture of the two streams, at their different temperatures, determines the water temperature at the core inlet, which, as noted above, is about $25^{\circ} \mathrm{F}$ below boiling. This $25^{\circ}$ is called the "subcooling." These points and definitions are important to understanding the accident.

The Chernobyl reactor had two separate circuits for flow of water through the core, each including about half of the pressure tube channels. Each circuit supplied water and steam to two steam drums, so there were four steam drums altogether. There were two $500 \mathrm{MW}$ (e) turbines, each taking steam from one steam drum from each reactor circuit, then returning feedwater to one of the cooling circuits.

The water was driven back to the core inlet by primary circulation pumps. Each of the two circuits had four pumps in parallel, though usually only three were used and one was kept on standby. The pumps supplied a forest of pipes under the reactor that fed water to the separate pressure tubes.

There were 211 control rods, all hung from cables that wound on drums driven by electric motors. Power and neutron flux distribution were measured in-core by self-powered ion chambers, which are devices that do not give reliable information at lower power. At lower power, during startup and shutdown operations, ion chambers in the graphite reflector about the core were used.

There was also an emergency core cooling system (ECCS) that resembled the ones used in American pressurized water nuclear plants.
This was meant to continue core cooling if, for some reason, ordinary cooling methods did not work. Reference to this system appears in the chronology of the accident, but the ECCS played no real part in the events.

There was a partial containment system, the characteristics of which are important. The containment system for the RBMK's was based on compartmentalizing the reactor structure. Separate rooms with strong walls surrounded individual components of the plant. The reactor core of graphite and pressure tubes was in one such room, with a capability of withstanding a pressure of about $26 \mathrm{psi}$. The steam drums were in two other such rooms. The pumps may have been in two other strong rooms, four to a room. It is a little difficult to know the exact structural details because they differ somewhat among several RBMK designs, and sometimes the drawings that have been shown as Chernobyl turn out to be RBMK's at Leningrad or Smolensk or Kursk.

Below the Chernobyl reactor was a series of water pools that were meant to capture and condense any steam released if there were a pipe break or some other failure in one of the containment rooms. A system of relief valves and ducts led from the containment rooms to these suppression pools. This system would help if there were small leaks, but it could not handle a large-scale core disintegration.

Figure 3 shows a section of the reactor building. In it can be seen the core; the pipe galleries above, below, and in compartments at the sides; the pumps; the steam drums; the reloading machine; and the suppression pool at the bottom. Adjacent to the main building was the turbine hall. Figures 4 and 5 show slightly different views.

The RBMK's were usually built in pairs. Figure 6 shows a cross-section perpendicular to the previous ones, with Units 3 and 4 at opposite sides of the main building. In the foreground is the turbine or machinery hall, with the four turbines of the two reactors. Turbines 7 and 8 belonged to Chernobyl 4 , which had the accident. Turbines 1 through 4 belonged to Units 1 and 2, which occupied a separate building at the site. Figure 7 in this series is a view of the floor of the refueling hall above the reactor. The removable roof blocks above the fuel channels and the control rod drive units are visible in front of the refueling machine. 


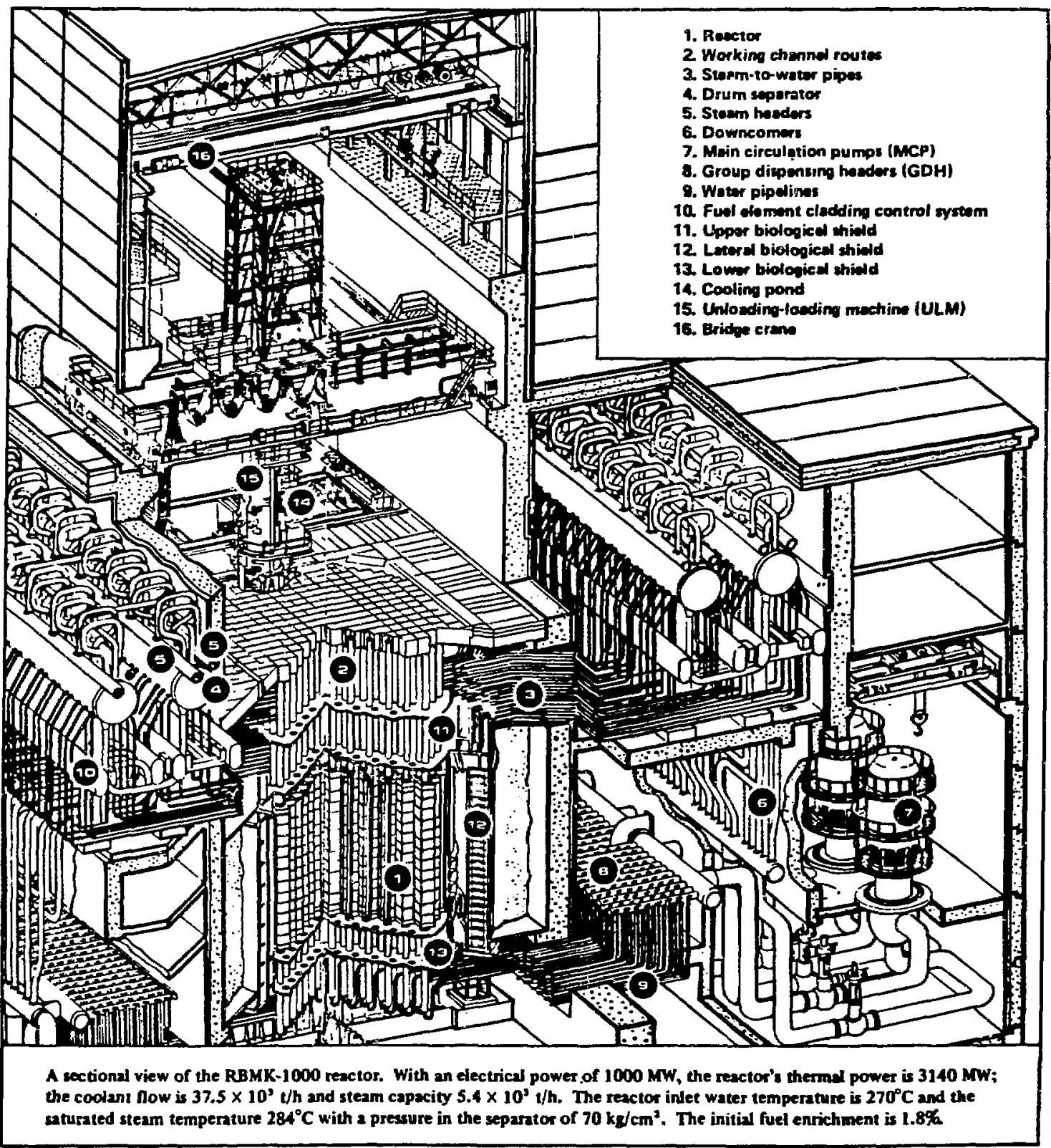

Figure 3. Sectional View of RBMK-1000 Reactor. 
Key: (1) first stage condensate pump. (2) 125/20t overhead travelling crane. (3) separator steam superheater. (4) K-500-65/3000 steam turbine. (5) condenser. (6) additional cooler. (7) low pressure heater. (8) deaerator. (9) 50/10t overhead travelling crane. (10) main circulating pump. (11) electric motor of main circulating pump. (12) drum separator. (13) 50/10t remotely controlled overhead travelling crane. (14) refuelling machine. (15) core. (16) accident containment valves. (17) bubbler pond. (18) pipe aisle. (19) modular control board. (20) location beneath control board room. (21) house switchgear locations. (22) exhaust ventilation plant locations. (23) plenum ventilation plant locations.

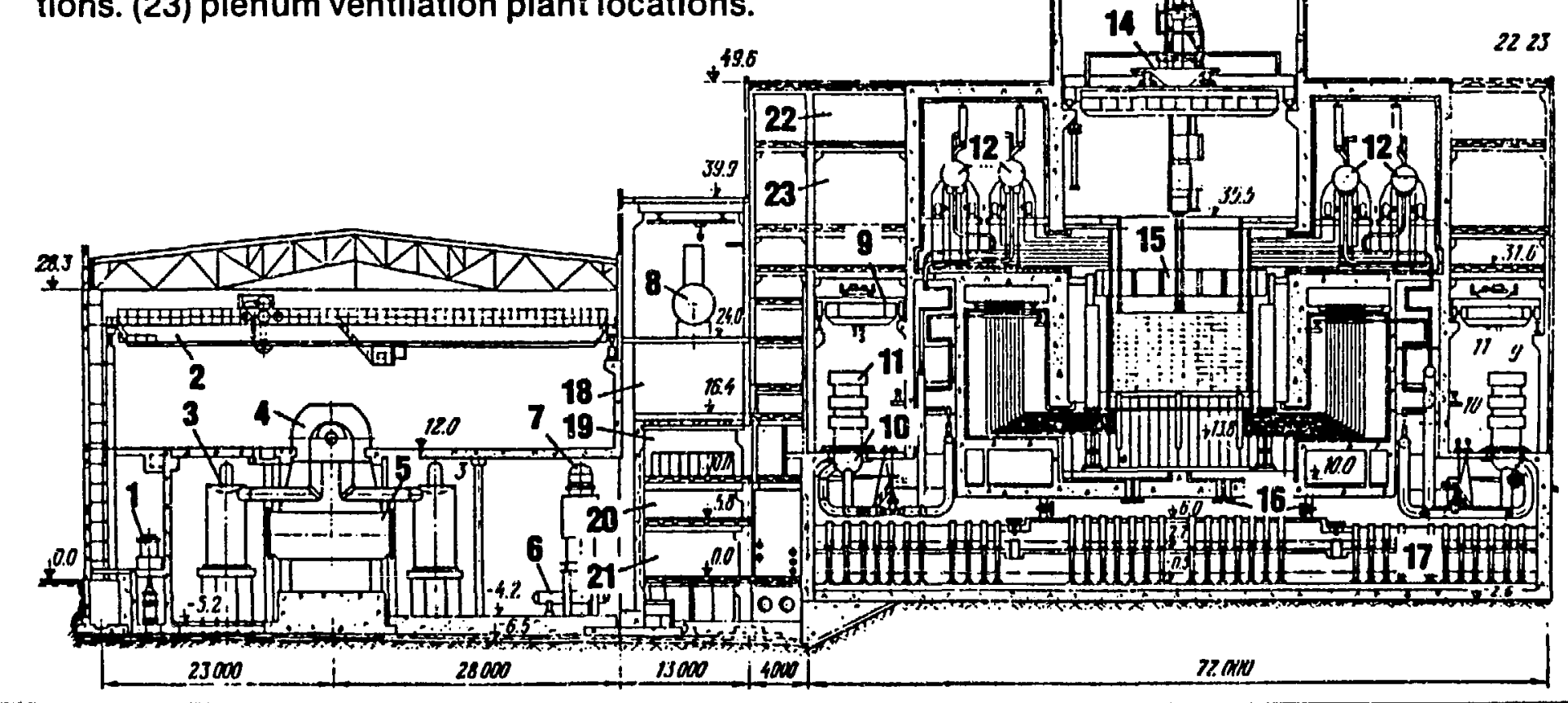

Figure 4. Cross-Sectional View of an RBMK-1000 Main Building, of the Chernobyl Type. 


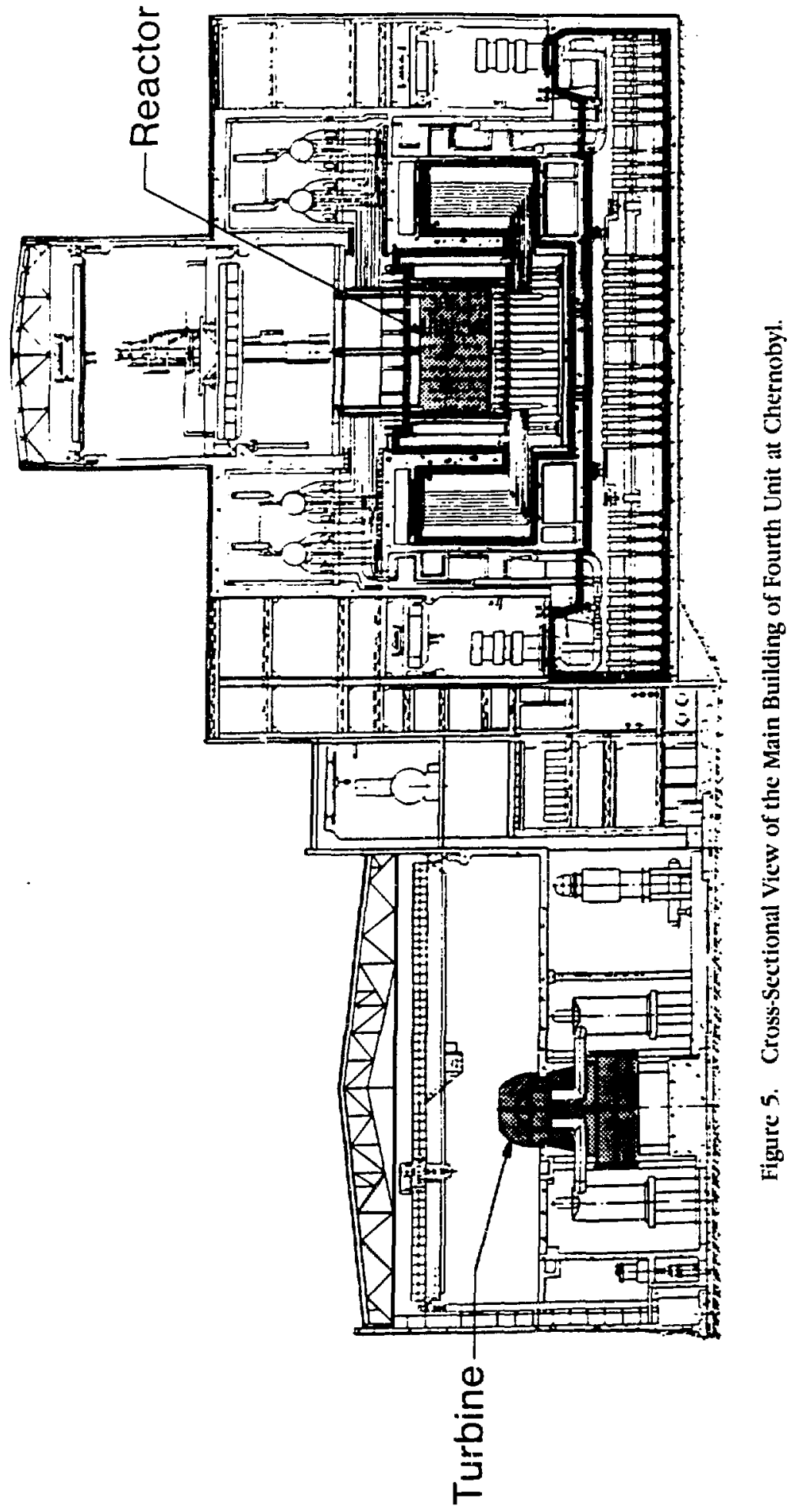




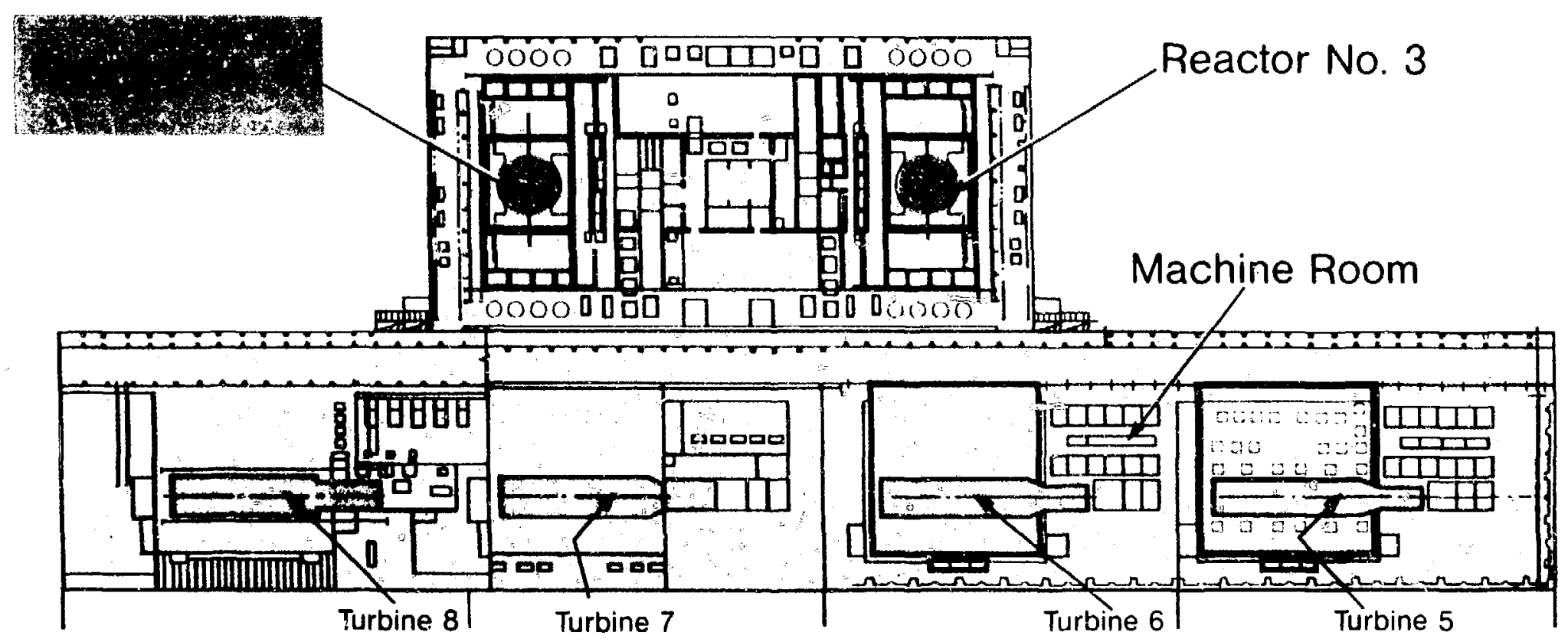

Figure 6. Layout of Main Building of Fourth Unit of Chernobyl Atomic Energy Station. 


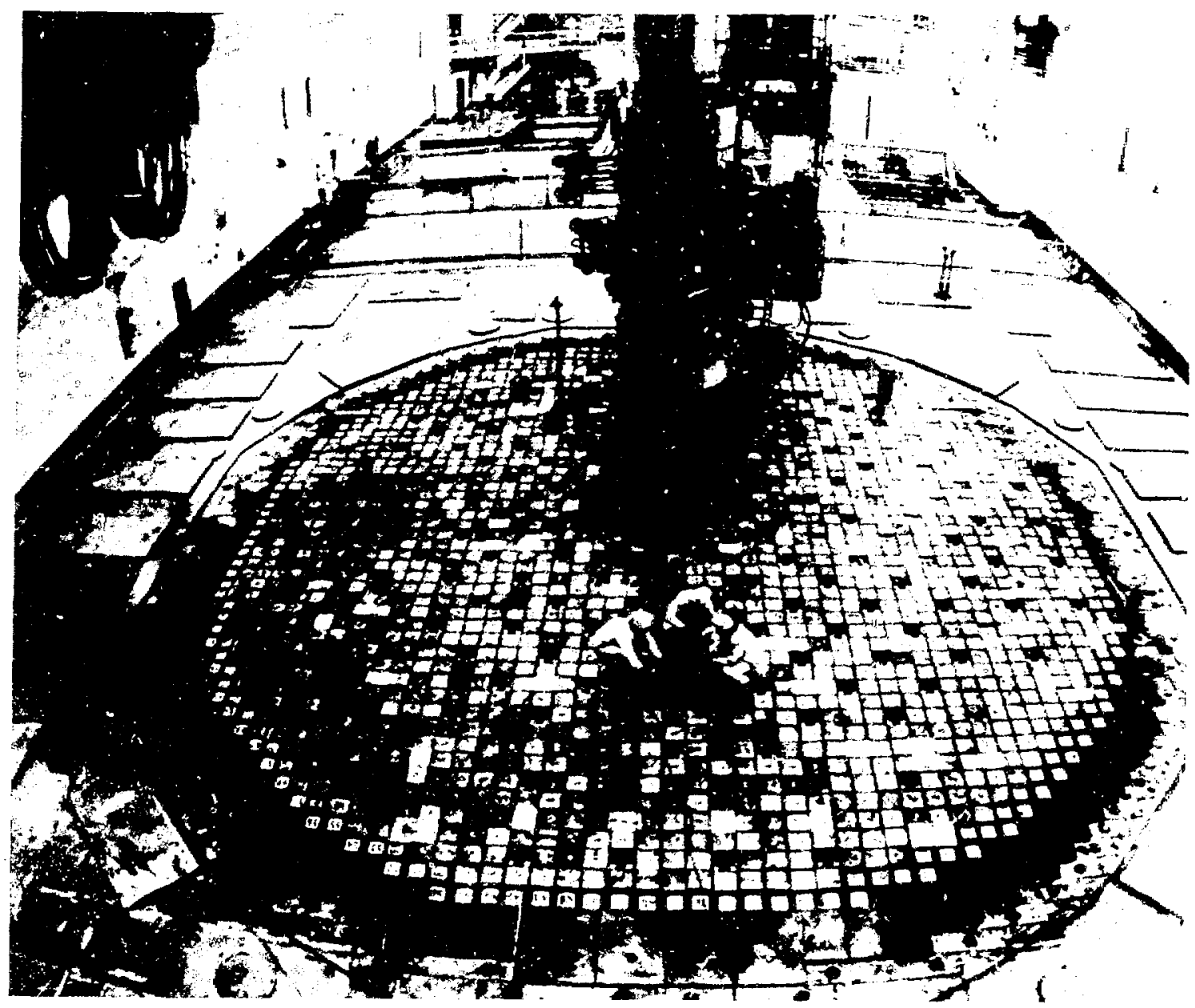

Figure 7. Reactor Refuelling Hall.

One unfortunate characteristic of the RBMK reactors is that they all have positive void coefficients: that is, increasing the steam fraction in the core by increasing the boiling rate makes the reactivity increase. Yet increasing reactivity means increasing power, which causes more steam void, and so on. Therefore, the reactor would be completely unstable in practice except that at higher power, other competing factors introduce stability. Startup and shutdown required taking the power level through regions of instability below about $600 \mathrm{MW}(\mathrm{th})$. Because of the instability, there was a rule that extended operation was not permitted below $700 \mathrm{MW}$ (th).

The accident took place during an experiment conducted at the start of a normal reactor shutdown scheduled for routine maintenance. The operating staff had prepared to do what they considered to be a routine safety test of some electrical control equipment. They took a series of steps - some by accident and some intentional - that caused this routine test to destroy the Chernobyl Unit 4 reactor.

The test was to determine the ability to continue to draw electrical power from a turbinegenerator coasting down during the first minute of a "station blackout transient," a term used to denote loss of electrical connection to the transmission lines so that the nuclear plant can neither supply electricity, nor receive it. In this case, the reactor automatically shuts down, or scrams. Like U.S. nuclear plants, the Soviet plants have diesel generators to take over if 
transmission line connections are lost, and these generators would supply power for essential components and services. They take nearly a minute to start up and come on line. In previous tests, presumably at a different RBMK reactor, it was found that as the turbinegenerator slowed down, the output voltage fell more rapidly than was desired. A new control circuit had then been added to the generator to compensate for the voltage reduction, and the test to be made was meant to show how well this new circuit worked. The staff at the reactor focused their attention on the question of how well the electromechanical equipment worked, and they did not pay attention to reactor effects. The test was under the control of an engineer from the organization that supplied the new voltage control equipment.

The intent of the test was to reduce the reactor power from its normal level of 3200 MW(th) to a value between 700 and 1000 $M W(t h)$. One of the two turbine-generators would then be switched to provide power to four main circiation pumps, thus simulating the load that the generator would be expected to carry during its deceleration. The flow of steam to the turbine wouid then be stopped while the reactor was scrammed. This form of the test had been performed in the past, and it had been approved as safe.

At 0100 in the morning of April 25, the reduction of power began for the scheduled shutdown. To avoid damage to fuel channels from too rapid cooling, the power of an RBMK is decreased slowly. It was 1300 in the afternoon, twelve hours later, when the power had been lowered to 1600 MW(th). At this point, the grid controller asked that the plant be kept on line to supply electricity for the national grid. Power reduction was stoppeci and turbine 8 , which was scheduled to be used in the electromechanical test, continued to supply electricity to the grid and to three main circulation pumps for the next twelve hours. Three other main circulation pumps that fed water to the second core loop were transferred from turbine 7 to the external transmission line supply, and turbine 7 was then stopped by transferring all steam supply to turbine 8 . The remaining two pumps were on standby, one to receive power from the external grid, and one from turbine 8.
An hour later, in preparation for the test, the Emergency Core Cooling System, or ECCS, was blocked off for unknown reasons. This step was not required by the test. The plant continued to operate for ten more hours in a state wherein the ECCS would not have worked if it had been needed. This was a severe violation of the regulations. The locking out of the ECCS played no part in the accident that followed, but it does indicate something about plant safety operations. The nuclear plant operators at Chernobyl had a reputation as the best nuclear plant crew in the Soviet Union. They had come to believe that their abilities were so superior that nothing they did was really wrong. They understood the reactor, and they were its masters.

At 11 PM (2300) the grid controller released the reactor from its requirement to supply power. The reduction in power level resumed. About 90 minutes later, an event occurred that set the stage for the accident. As the reactor power approached the $700 \mathrm{MW}(\mathrm{th})$ level viewed as minimum for the test, it became necessary to switch reactor control from the "local" to the "global" mode. The local mode depended on the self-powered flux detectors distributed throughout the reactor, which did not work well at the lower power. The global mode used during normal power ascension used conventional neutron detectors in the reflector of the reactor. This is not a satisfactory mode for high operating power. When the transfer from local to global mode was made, the operator neglected to signal the control system to hold the power level steady. The power level began to decrease rapidly, and it fell to an estimated level of $30 \mathrm{MW}$ (th) before the operator could halt the drop by control rod motion.

It is important to note that the reason for the intended $700 \mathrm{MW}$ (th) minimum power level for the test was that the regulations prohibited operation below this level. Operation became unstable below this value. The ability to control an RBMK at design power is based on the fact that, at this power level, the power coefficient is negative. At lower reactor power, the power coefficient becomes positive, and a positive power coefficient causes an extremely unstable condition. Any departure of the power level from a steady value accelerates in the direction of the departure, whether up or 
down, and must be caught and reversed quickly if the original power level is to be restored. Controlling a reactor with a positive power coefficient is like trying to balance a baseball on the end of a watermelon.

So after the operator had stopped the precipitous power drop, he maneuvered it back up again, and managed to achieve some measure of control at a reasonably steady power level of $200 \mathrm{MW}$ (th). It was decided to run the test under these conditions, in absolute violation of regulations.

Yet there was another violation implicit in the state of the reactor. The safety of RBMK reactors, having positive void coefficients, depends on the ability to insert negative reactivity quickly through control rod action. The regulations required a minimum number of 30 control rods in the reactor, inserted to a point at which they reduce reactivity quickly when they are moved in. From this point in the chronology of the accident, the number of control rods in the reactor was far lower than regulations permitted. This situation developed largely because so many control and safety rods had to be removed to compensate for the reduced steam void volume in the core, among other reasons. Incidentally, the Soviet experts at the Vienna post-accident meeting said that the state of the reactor at this point absolutely demanded that it be shut down. Yet this was not done.

It was now 1:00 in the morning of April 26, with reactor destruction only a little more than 20 minutes away. Another step was taken which complicated the situation significantly, and may have contributed to both the possibility of the accident and its magnitude. The two idle main circulation pumps were turned on, one powered from the grid and the other from turbine 8 . This action led to a circulation flow greater than normally expected at full power, when only six pumps were used. At this increased circulation flow rate, the pumps neared a danger point at which they become ineffective, and were on the verge of cavitating. The Soviet report raises this point, but then is quiet on it later. Thus we do not know if pump cavitation played a part in the accident, though if it occurred, it would have been an important contributor.

The four pumps powered by the grid were on because the test would be run a second time if it failed the first time. Also, the four extra main coolant pumps were to continue supplying core cooling when the other four stopped, following their coastdown.

At this point, at $1: 18$ in the morning, we enter the time covered by a Soviet calculation of the accident. The results of this calculation were supplied as Figure 4 in the Soviet report at Vienna, presented as Figure $\mathbf{8}$ ( see fold-out on page 19). The figure shows the state of the system starting at $1: 18$ in the morning, about six minutes before core destruction, and continuing to $1: 24: 48$. At about 1:19:10, the operator began to increase the rate of feedwater return to the point at which it joins the recirculation flow just beyond the recirculation flow takeoff at the steam drumis. He did this to reduce the recirculation fiow, because he decided that the water level in the steam drums had fallen too low. Since feedwater is cooler than recirculation flow, the feedwater is a strong determinant of the subcooling. As the feedwater rose to about three times the equilibrium rate at $200 \mathrm{MW}(\mathrm{th})$, several effects occurred. The steam drum water level did begin to slowly increase, but the reduced temperature of inlet. water to the reactor core reduced the rate of boiling, and at about 1:19:45, boiling stopped altogether. The reactor operated for about two minutes as a pressurized water reactor.

The core reactivity was also affected. The collapse of the steam voids in the reactor reduced the reactivity, and control rods were withdrawn, some completely out of the reactor, and some to positions of low effectiveness. The Soviet report says that only 6 to 8 rods were in the reactor at this point, rather than the required number of 30 .

Then, to avoid any possibility of reactor trip resulting from steam drum or feedwater signals, the operator locked out the scram circuits associated with these variables. This was at least the fifth serious violation of safety regulations.

At 1:21:55, the operator began to reduce feedwater flow, which by this time was up to four times the equilibrium rate. At 1:22:10 boiling began again in the core. The effect on reactivity was dramatic, which showed how sensitive the reactor was to small changes in core inlet coolant conditions. At 1:22:10, rod bank AR1 began to drive into the reactor, reaching 
$90 \%$ insertion in 20 seconds. At 1:22:25 rod bank AR3 began to enter the reactor again. At this point, feedwater flow was about $2 / 3$ the equilibrium rate for $200 \mathrm{MW}(\mathrm{th})$. Rod bank AR 1 responded violently for nearly a minute as the operator tricd to establish the right setting.

At 1:23:04 the planned test began with closure of the turbine stop valve for turbine 8 . This stopped steam flow to the turbine and effectively turned the turbine off to start its coastdown. Shortly before this, the operator had committed his sixth - and most deadly violation of safety requirements: he blocked the scram circuit that would have shut the reactor down resulting from a turbine trip. If he had not blocked the scram circuit, then the accident would never have happened, in spite of his five previous violations. The reactor would have been safely scrammed with all safety rods inserted at about 1:23:25, a full 17 seconds before the final destructive power rise.

After the turbine stop valve was closed, the core inlet flow rate slowly began to diminish. The transport of heat from the reactor started to fall, and the steam void fraction in the core began to rise, adding reactivity. The first effect on reactivity was negative, resulting from the pressure surge in the steam drums when the turbine stop valve closed. One bank of safety rods started out of the reactor (1:23:10) and then immediately reversed to start insertion as the steam void fraction continued to increase (1:23:21). A second bank of rods joined in the inward motion in about five seconds ( $1: 23: 26$ ), as the automatic power controller sought to compensate for the rising reactivity from the slow increase of steam void fraction in the. core. About six seconds later (1:23:32), the third and last of the rod banks still in the reactor joined in the attempt the reactor was making to save itself.

Eleven seconds later (1:23:43), all three of these banks of rods were fully inserted, but this was not enough. The reactor power level had already risen from its initial value of 200 $M W($ th ) to a value far above the normal operating value of $3200 \mathrm{MW}(\mathrm{th})$. This increase had taken less than three seconds. The high power and short reactor period warning signals sounded at about this time. The operator activated the reactor scram button, but there was no time left. Further control rod insertion would not have had any beneficial effect before about six seconds had elapsed. in one second more the power of the reactor was at a level estimated to be a hundred times normal operating power, or above $300,000 \mathrm{MW}$ (th). One second after that the reactor was destroyed.

Observers outside the reactor building reported hearing two explosions separated by about two or three seconds. The first was said to have sent projectiles through the roof of the reactor building. These must have been either the removable roof blocks, or the refueling caps from the pressure tubes. The Soviet report states that in this first explosion, the fuel disintegrated into fine particles that were expelled into the coolant, causing an almost instantaneous pressure surge. This surge apparently drove a column of coolant upward, expelling refueling caps; drove another column downward, destroying piping below the core; and created sideways pressure which burst the pressure tubes of at least some coolant channels. This action released steam at primarysystem pressure into the vault containing the reactor core. The 1000 tonne cover plate of this vault was lifted by the pressure surge, shearing off the tops of all tile pressure tubes. This lifting of the cover plate also puileci out any inaining control rods from the reactor core, since:the rod drive mechanisms were mounted on the top cover plate. The plate itself came to rest standing on edge above its former location. All fuel channels and the entire core structure now had been opened to the environment. The second explosion was undoubtedly the cover plate lifting and shearing the fuel channels, thereby releasing steam at primary system pressure to the exterior. There may have also been explosions from hydrogen then, or at a later time, but these would have been incidental.

The explosions threw hot fuel and graphite high into the air. Observers in Pripyat, who were still out in the street, said it looked like a fireworks display. Hot projectiles falling back on the roof ignited asphalt roofing material, and a fierce fire started. Fire departments called from the nearby towns of Pripyat and Chernobyl, fought the fire until $5 \mathrm{AM}$, over three hours later. The firemen were severely hampered by the high radiation fields, by lack of high lifter equipment that could put them on the roofs of the buildings, and by inadequate 
protective clothing. Indeed, fatalities were alf among fire-fighters and operating personnel of the reactor. All during this period, while fires were raging on the roofs and high radiation fields were present everywhere, Unit 3 continued operating, presumably to supply power needed for firefighting. Unit 3 was later shut down when the fire was put out. The nearby Units 1 and 2 continued to operate for another 20 hours.

Local reactor management personnel were said to have informed Moscow that a problem existed, but insisted that they could control the situation themselves. At the Vienna meeting, the Soviet expert who related this said that when Moscow was informed, there was no longer any reactor to control. He said that Moscow immediately senî emergency medical and radiation safety teams.

The inhabitants of the nearby town of Pripyat were told at first to remain indoors with their windows closed. By the next day radiation levels in the area began to rise, and the inhabitants were evacuated. Potassium iodide tablets were distributed door-to-door by Young Communist league members before the evacuation. The evacuation itself was managed by door-to-door hotification. Over the next few days, all population centers in a radius of about $30 \mathrm{~km}$ were evacuated in an exercise involving some thousands of buses commandeered from as far away as Kiev. About 135,000 people were evacuated in this exercise. Some tens of thousands of cattle were also evacuated in truciss. Figures 9 and 10 show the locations of principal cities in the region and the evacuation zone.

The emission of radionuclides continued for about nine days, aided by burning of the graphite. It is estimated that upwards of ten percent of the graphite in the core burned, in a manner similar to the rapid oxidation of charcoal. The Sovict emergency teams tried to put out the fire and stop the emission of radioisotopes by dropping massive amounts of mate. rials ifom helicopters. The estimated amounts of materials dropped on the core were $\mathbf{4 0}$ tonnes of boron carbide, 800 tonnes of dolomite, 1800 tonnes of clay and sand, and 2400 tonnes of lead. Since dolomite is a carbonate of calcium and magnesium, it was used because it decomposes at high temperature to produce carbon dioxide which would help to extinguish the fire. Figures 11 and 12 show the

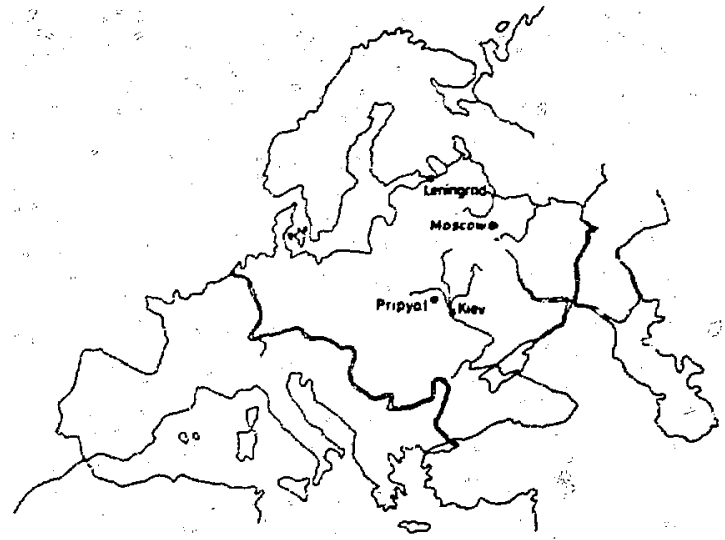

Figure 9. Map of Europe and Russia Showing Principal Cities.

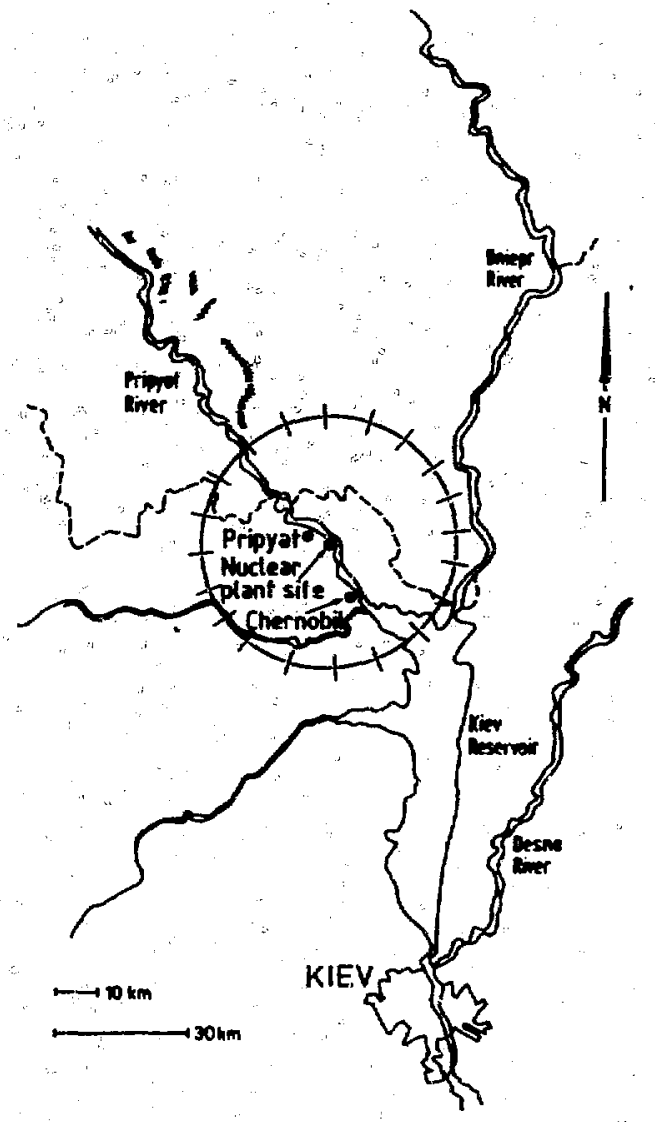

Figure 10. Map of Plant Site Showing Evacuation Zone. 


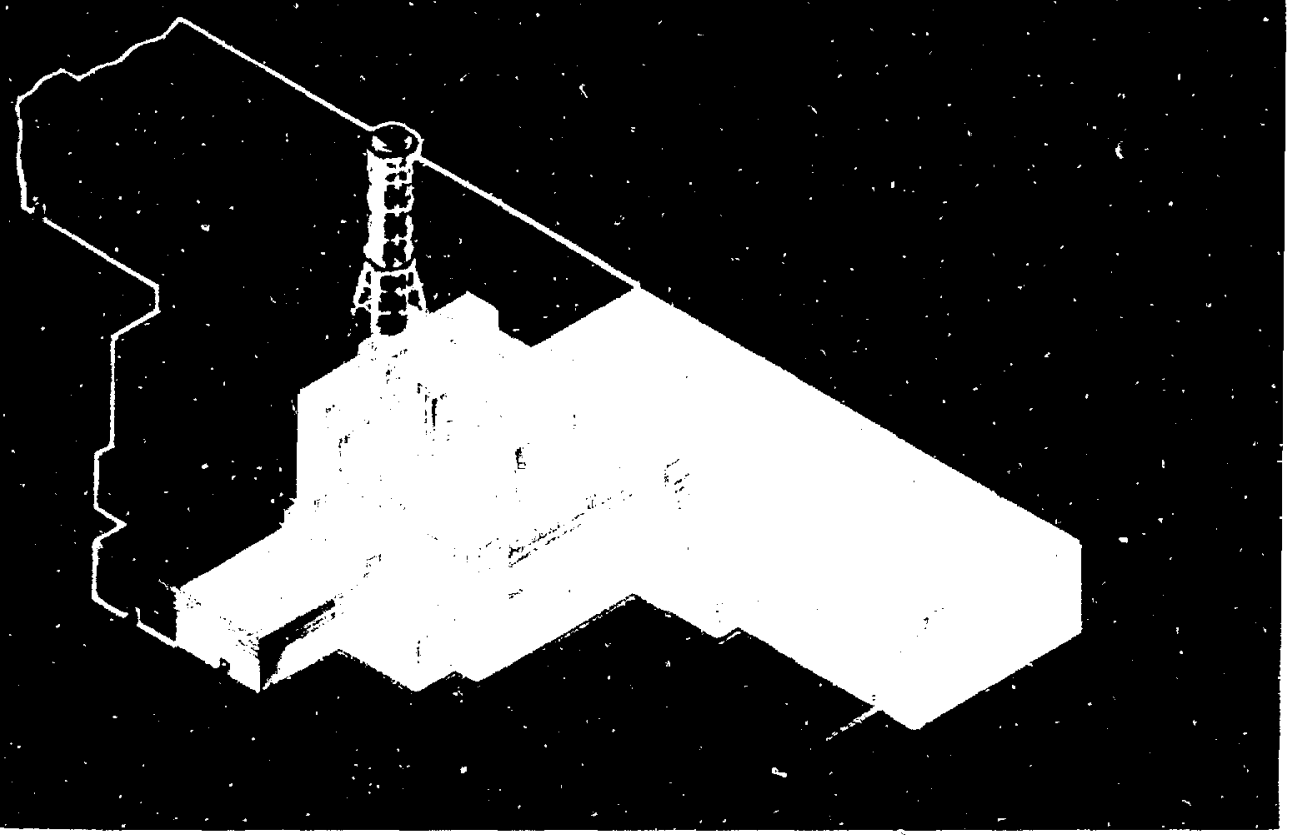

Figure 11. General View of the No. 3 and 4 Units Before Accident.

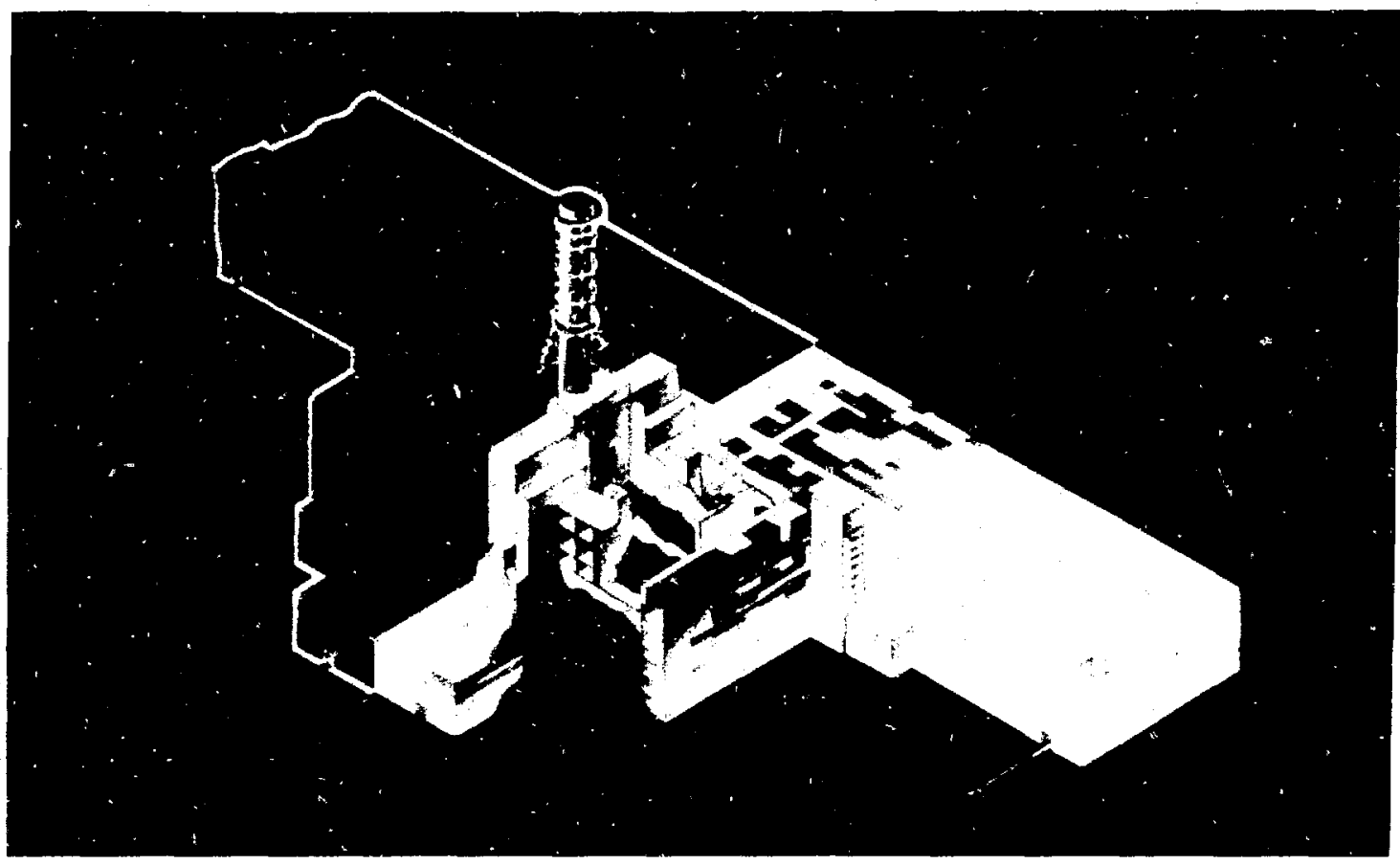

Figure 12. General View of the No. 3 and 4 Units After Accident. 
number 3 and 4 units before and after the accident; Figure 13 is a computer modelled cross section view; and Figure 14 is a wire service view of the damaged reactor building.

For a time, however, the effort to extinguish the fire and control radioisotope emissions seemed to be counterproductive. After the fifth day, the rate of emission of radionuclides rose again, as shown in Figure 15. The amount of activity addeci to the environment during the next five-day period may have exceeded that of first five-day period. This effect may have been caused by the debris heating up because it was insulated by the materials dropped on the core. On the fifth day, the emergency team began to pump liquid nitrogen into the space under the reactor, in part to cool the debris, but also to put out the fire by inerting. On the tenth day, the emissions dropped considerably and have continued to drop since then. The rate of emission is still not zero, running about a curie per day as of this writing.

About $\mathbf{5 0}$ megacuries of activity have been emitted, including that blown out in the first explosions and during the fire. It is estimated that all of the noble gases xenon and krypton were released, and that about ten to twenty percent of the volatile elements iodine, bromine, cesium, and tellurium were emitted. of the remainder, about $3 \%$ to $5 \%$ were released in about the same concentrations in which they existed in the fuel before the accident. This surprising effect apparently resulted from aerosol release of fine particles generated at the time of initial fuel damage. This is the basis for the Soviet belief that the fuel did not melt afterwards.

Since the emission continued for ten days, the path of the initial cloud of radioactivity did not determine the distribution of radioactivity to the rest of the world. The heat from the release carried the cloud high into the atmosphere; its subsequent motion was determined by the winds aloft. At first, the activity drifted to the northwest, where it was detected by Finnish and Swedish monitoring stations. Subsequent wind shifts carried the activity over Poland, Czechoslovakia, Austria, Switzerland, Italy, the Balkans, and then the rest of Western Europe. Other wind changes bore the activity over other parts of the Soviet Union. Transpolar air movements carried the northern motion of the initial cloud into the Orient and the United States, although radioactive decay

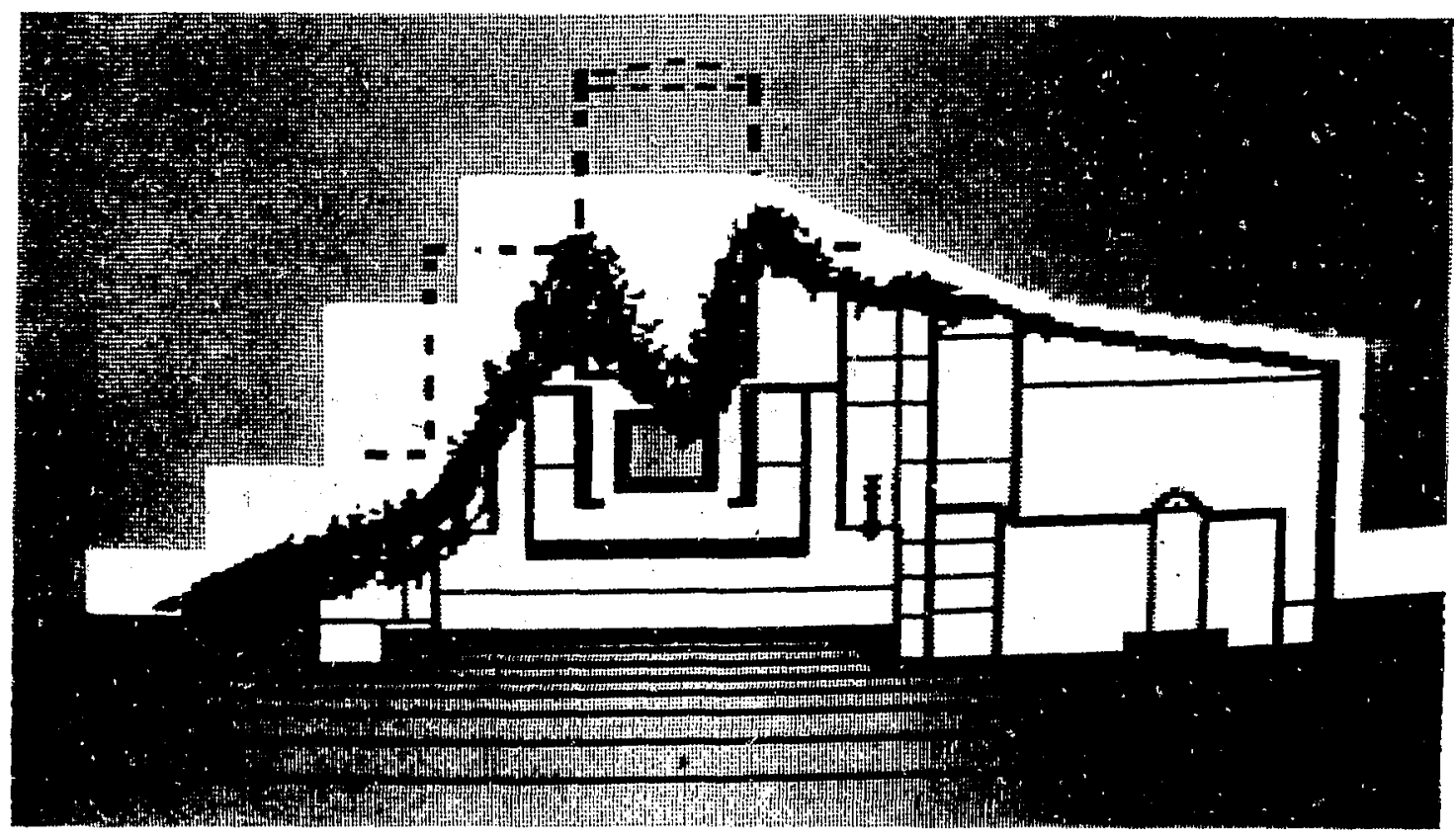

Figure 13. Schematic Model Section View of Chernobyl Main Building Showing Destruction. 


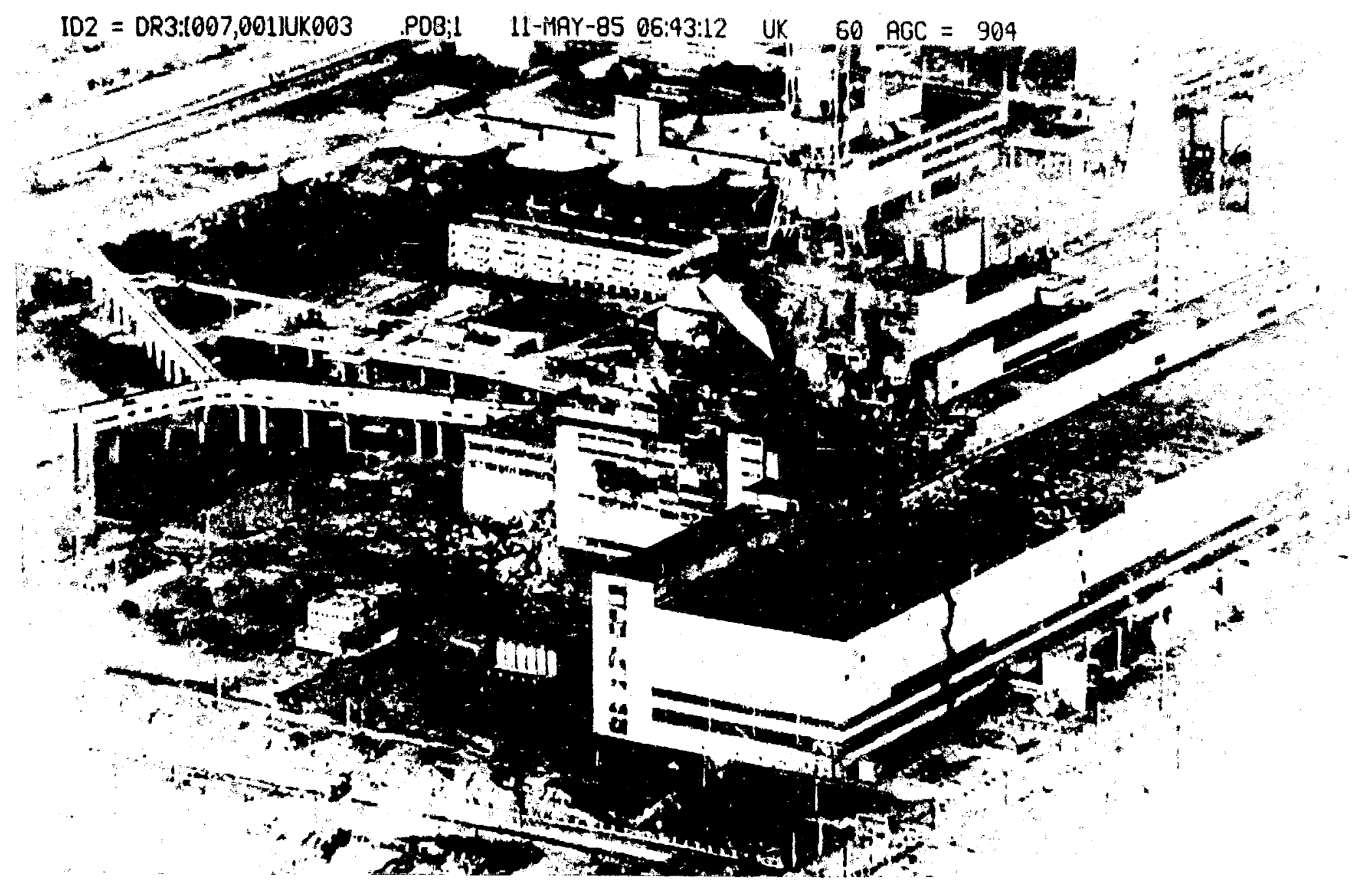




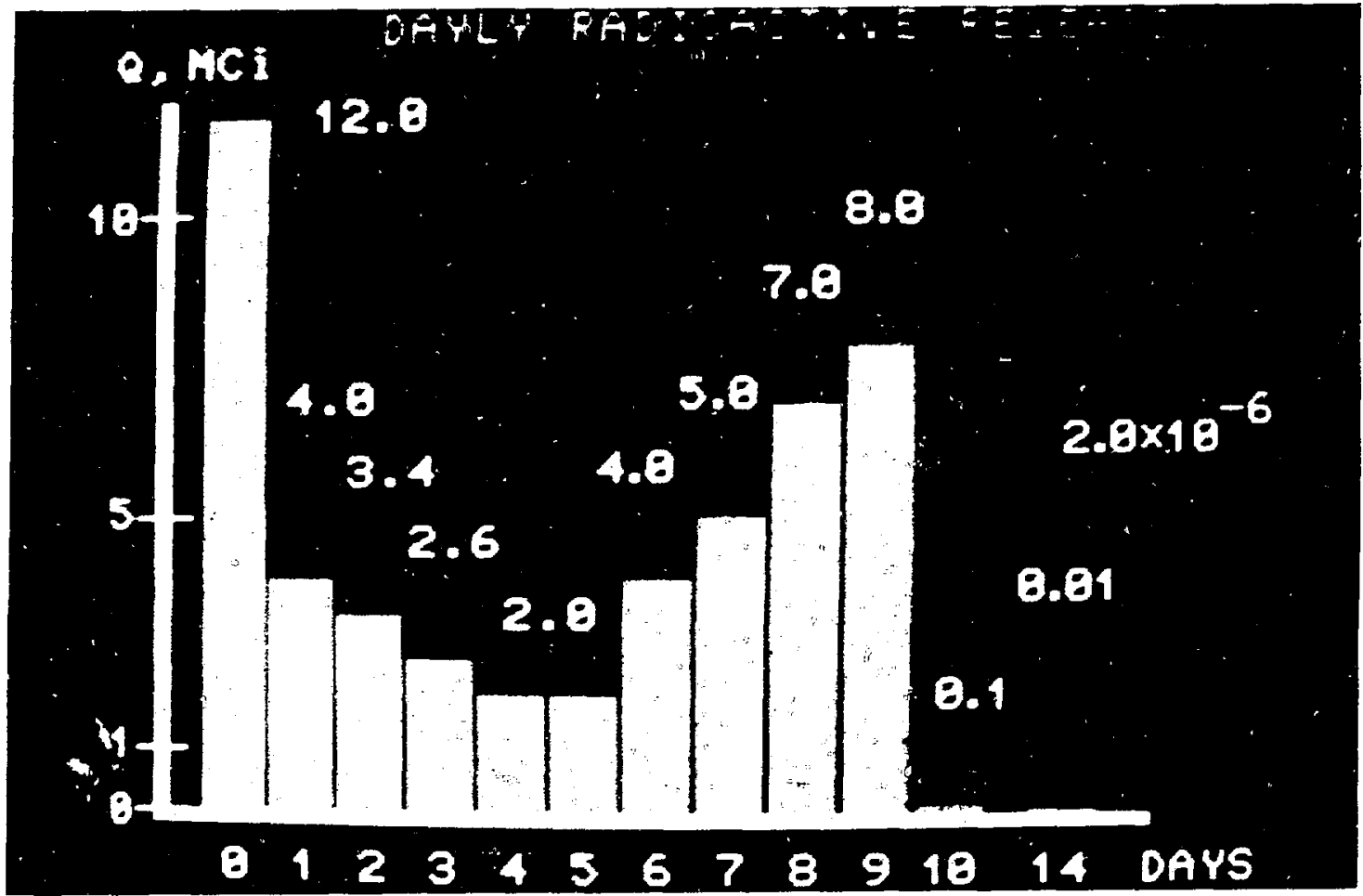

Figure 15. Radionuclide Emission Plot.

and atmospheric dilution caused the observed activity levels to be almost at background level. Figure 16 shows various particle plots over time in the Western European region.

In terms of health effects, by far the greatest part of the radioisotopes emitted remained in the Soviet Union. None of the evacuees from the $30 \mathrm{~km}$ radius evacuation zone displayed any symptoms of radiation sickness. Their collective dose from external exposure is estimated to be $1.5 \times 10^{6}$ man rem. The estimated number of cancers over the next 70 years from this exposure can be estimated conservatively from the linear, no-threshold assumption, at I60. This is an upper limit: as is well-known, there are no cases on record of cancers that can be traced to doses of radiation this low. At the same time, over the next 70 years the number of normally occurring cancers among the people evacuated is estimated as 27,000 . Even the upper limit estimate of delayed cancers resulting from the accident could not be detected statistically because the estimated number is within one standard deviation of the naturally occurring number (i.e., 27,000).

For the Soviet Union in generai, the $75,000,000$ people who will have received radiation doses of any appreciable amount would be affected even less. The increase in naturally occurring cancers over the next 70 years would fall in the range $0.03 \%$ to $0.15 \%$, again estimated according to the conservative linear, nu-threshold assumption. These estimates are based on radiation not yet received.

It is unlikely that the limited exposure of large populations will add any new information to the known effects of radiation, because these radiation exposures from Chernobyl are small compared to exposure from cosmic rays and natural radioactivity in the earth. On the other hand, knowledge of effects of acute radiation exposures may be advanced by studies of the $\mathbf{2 3 4}$ highly exposed individuals.

The Soviet Union is now proceeding to build a permanent vault around Chernobyl Unit 4 to reduce radiation levels near it as depicted in 


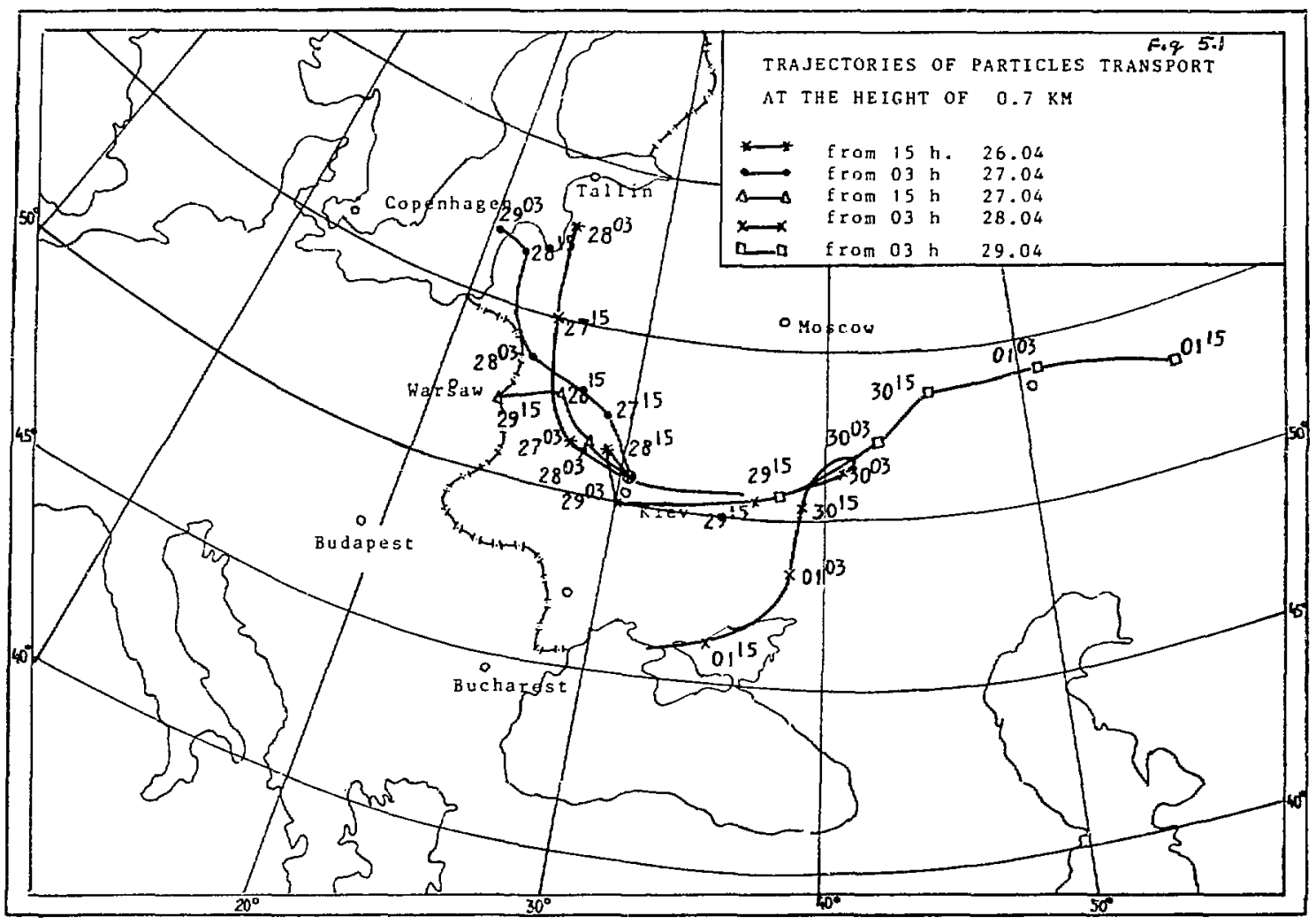

Figure 16. Trajectories of Particle Transport at $0.7 \mathrm{~km}$ Altitude.

Figure 17. Intensive measures are underway to restore the area around the plant to useful status. These measures include deep plowing of the land and decontamination of structures. Pripyat may remain uninhabited into the foreseeable future. But it is expected that Units 1 and 2 at Chernobyl will be started up again toward the end of 1986 , to be operated by crews rotated through from other RBMK reactors. A final decision on restart of Unit 3 has not been made as of this writing.

I would like to close with some thoughts about the accident, its causes and its consequences.

First, it is useful to note that many wrong things had to happen to generate this accident. The reactor design was unfortunate in linking instability to slow-acting safery systems. Even at that, the operators had to treat the unit almost with contempt, violating one restriction after another. U.S. reactors do not have the design problems of RBMK reactors, and we have no record of wholesale violation of the rules such as that which occurred at Chernobyl Unit 4 .

Second, it is important that containment be provided to protect the environment and the public from any possible reactor accidents. This requirement exists for U.S. reactors.

In these two observations, I do not wish to seem complacent about reactor safety. We should always remain vigilant about safety of nuclear reactors as we should about safety in other fields. I am simply pointing out that some of the important lessons from Chernobyl are among those we have already given our attention to.

The last point I want to make is that, although the destruction of Chernobyl Unit 4 may be almost the worst nuclear plant accident conceivable, it does not fall outside the range of effects of accidents of all other kinds. Indeed, 
the week we were in Vienna hearing about Chernobyl, a Soviet ship was sunk in the Black Sea with a loss of life which exceeded not only that of the emergency response personnel at Chernobyl, but also that conservatively estimated as possible for all the 135,000 evacuees from around the plant.
On the other hand, the Soviet estimate of the costs of the Chernobyl accident is $\$ 3$ billion. Once again we see the conclusion brought home by Three Mile Island: a bad reactor accident can be very expensive. The inducement to plant operators to keep them safe should be very high indeed.

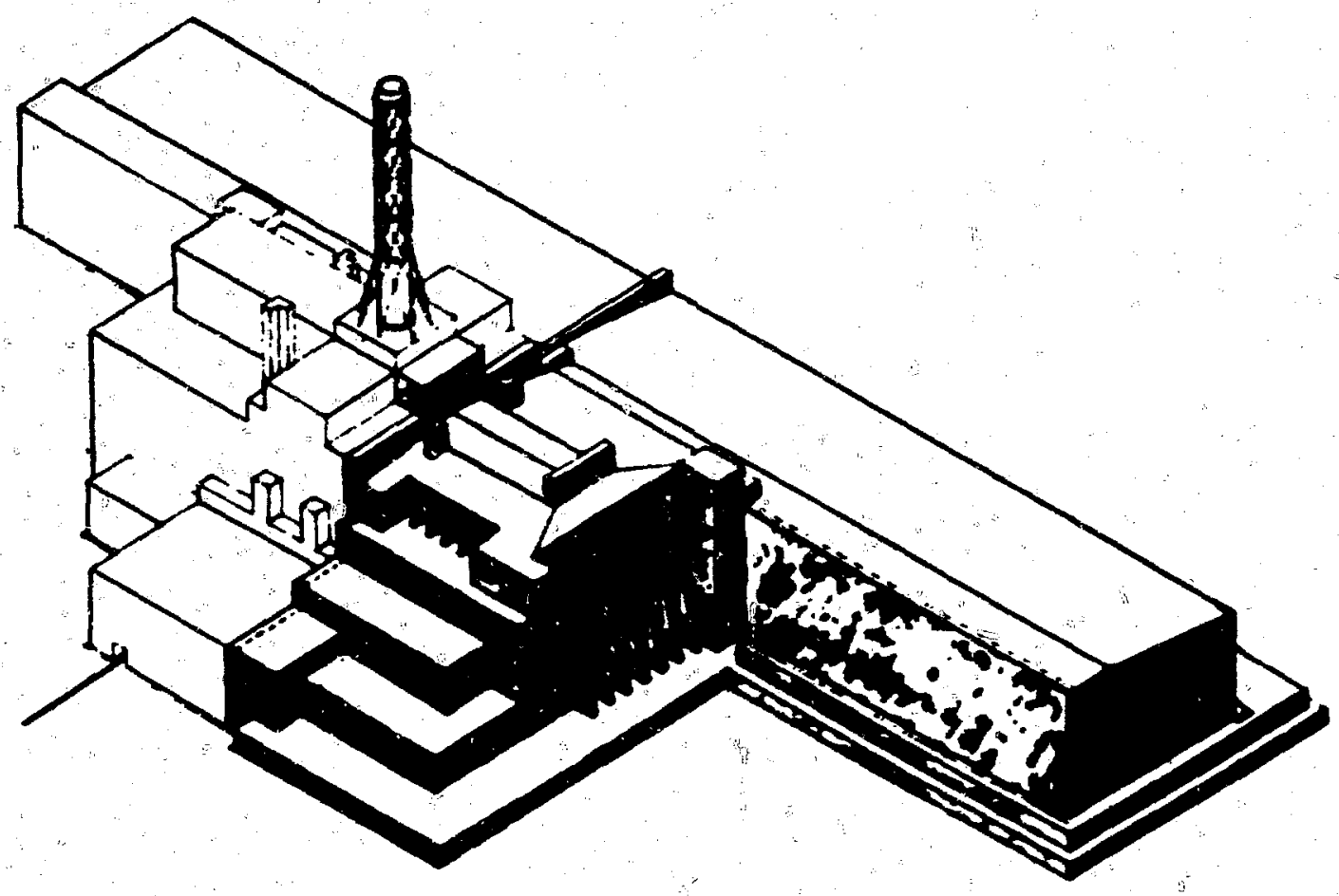

Figure 17. Conservation Scheme of Unit 4. 


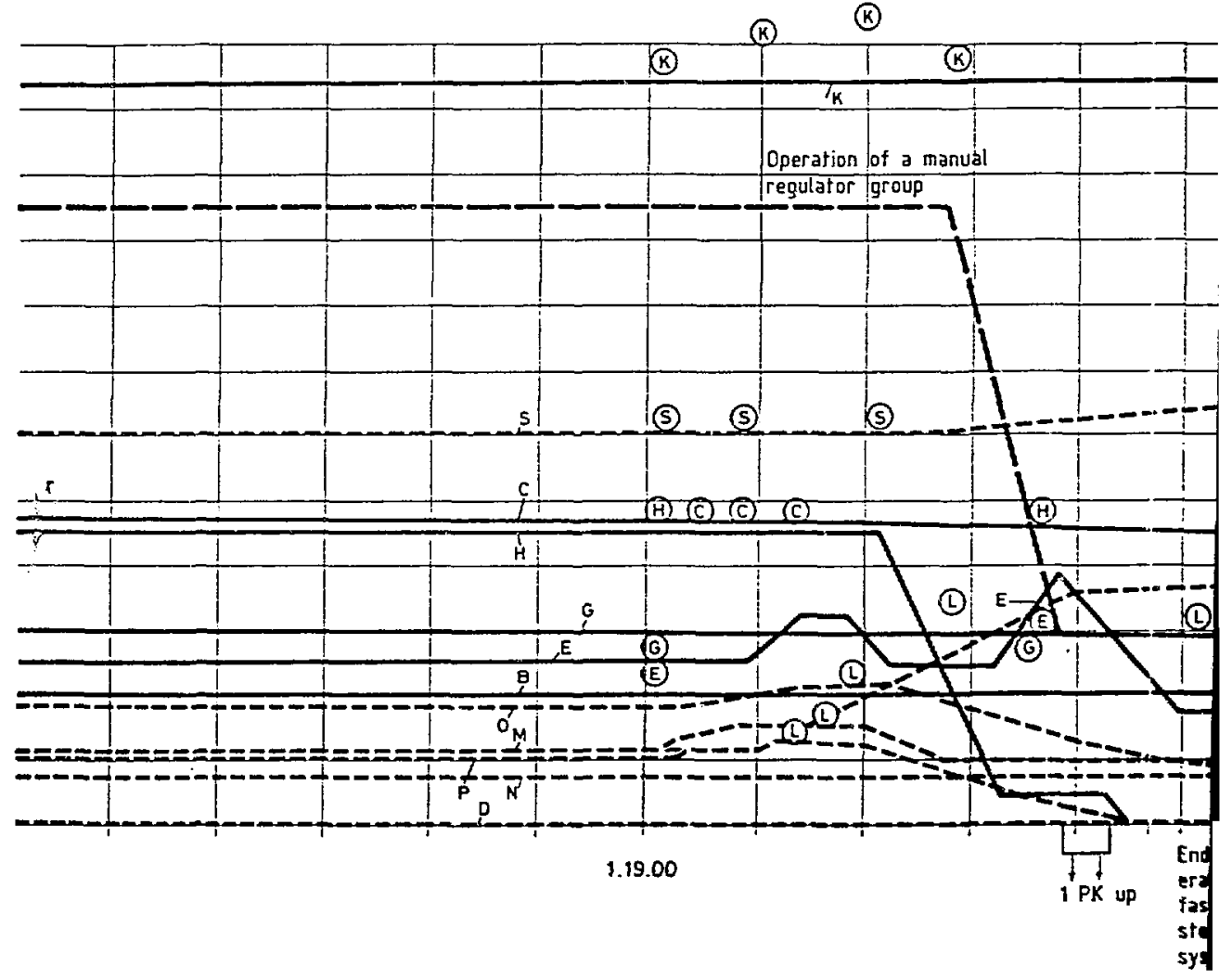


KEY TO THE CURVES

\section{$\underline{S Y M}$}

MIN MAX

- A Neutron power $(\%)$

- B Reactivity, sum. (\%)

- C Pressure, steam drum (bar)

--- D Neutron power $(\%)$

- E Rod grous AR-1 (fraction inserted)

- G Rod group AR-2 (fraction inserted)

- $H$ Rod group AR-3 (fraction inserted)

$\begin{array}{rr}0 & 120 \\ -1 & +5 \\ 54 & 90 \\ 0 & 48000 \\ 0 & 1.2 \\ 0 & 1.2 \\ 0 & 1.2\end{array}$

$\otimes$

$(\otimes$

(B)

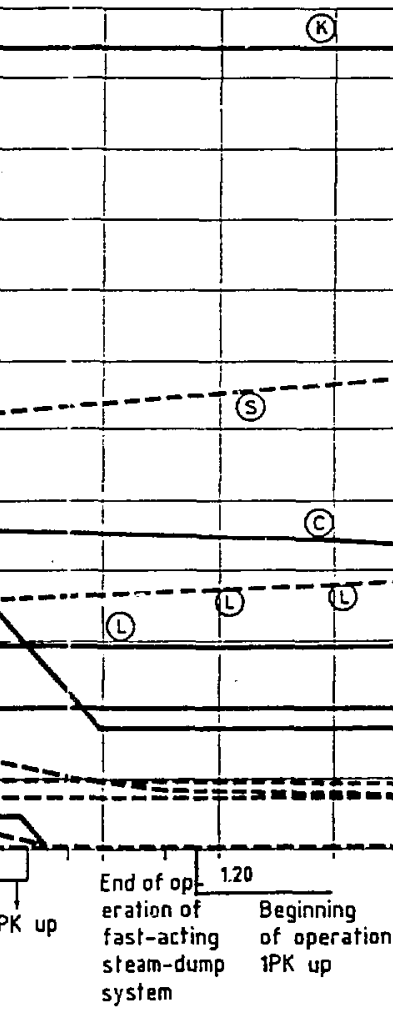

(c)

(5) (5)

(ब) 10

(B)

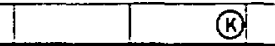

s!

T 1 (ब)

\begin{tabular}{l|l|l|l|}
\hline & & \\
\hline & & & \\
\hline
\end{tabular}

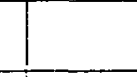

$+$

$-7 D^{-1}$

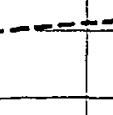

$1 \ldots+(5)$

\begin{tabular}{l|l|l|}
1 & & \\
\hline
\end{tabular}




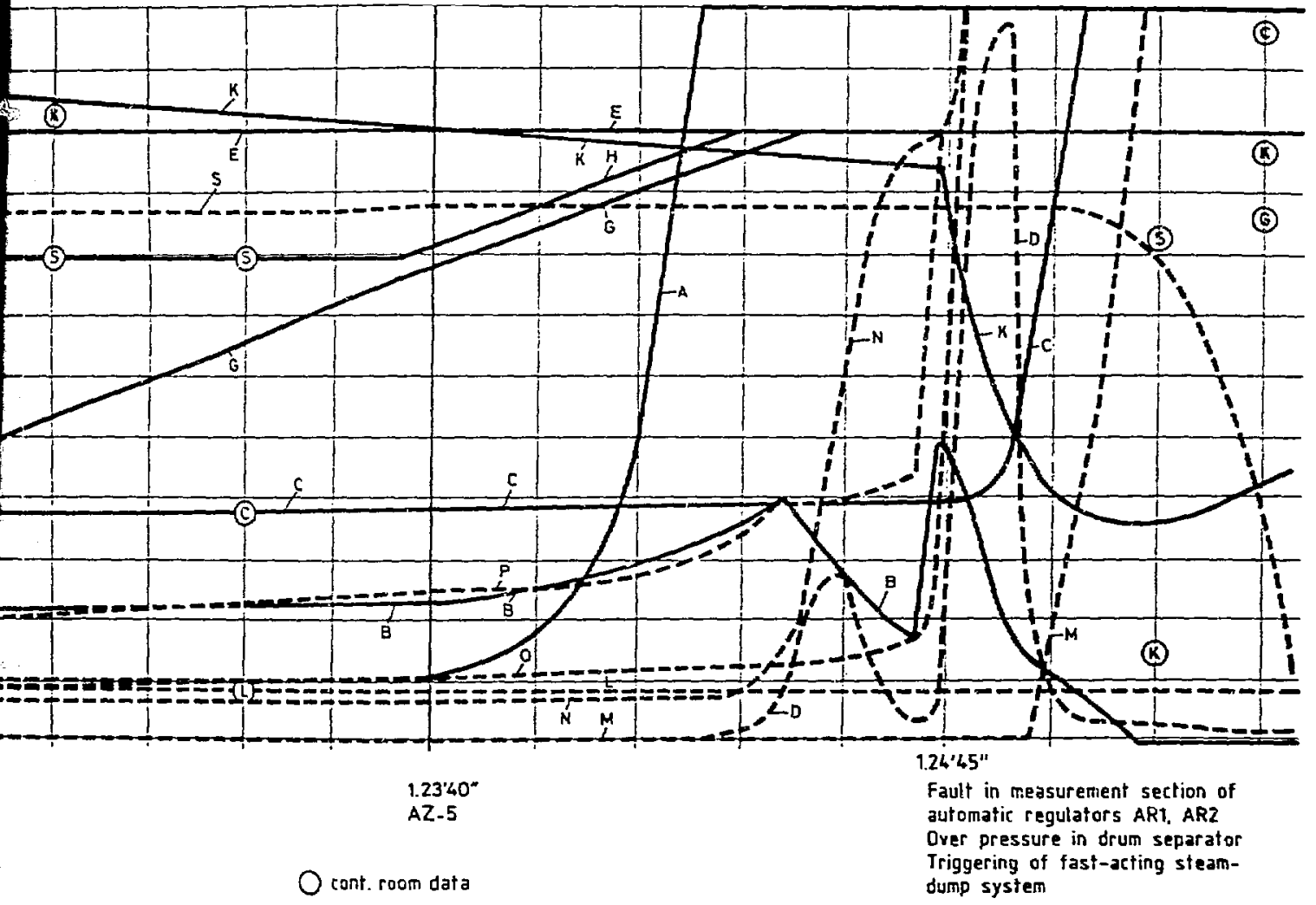

From FIG. 4 of the Soviet Working Paper vol.1

Figure 8. Chernobyl 4 State Plots 